\title{
REVISED Case Report: Two cases of rare head injuries from Nepal
}

\section{[version 2; peer review: 1 approved, 1 approved with}

\section{reservations]}

\author{
Joe M. Das (D1), Apar Pokharel(iD), Rashmi Sapkota1, Manish Mishra(iD1, \\ Ashish Babu Aryal ${ }^{1}$
}

V2 First published: 18 Sep 2018, 7:1483
https://doi.org/10.12688/f1000research.16225.1

Latest published: 22 Feb 2021, 7:1483

https://doi.org/10.12688/f1000research.16225.2

\section{Abstract}

Background: There are a number of ways in which one can sustain a head injury. Even if you are doing simple household activities or going out for a morning walk, you cannot be sure of what type of injury awaits you. The source of injury may be a pressure cooker whistle acting as a projectile or a hailstone falling from the sky. Such injuries are common in Nepal, considering the socio-demographic and geographic conditions. In this article, we present two such very rare cases of head injury.

Case Reports: The first case is a middle-aged woman who sustained an accidental injury to the face associated with fracture of frontal sinus and frontal contusion, following the impact from a high momentum projectile in the form of the pressure regulator of a pressure cooker. She underwent craniotomy and removal of the foreign body. In the second case, an elderly man sustained minor injury to the head following the fall of hail. The abrasions and contusions produced by the hail were managed conservatively. Since he did not have any clinical evidence of head injury, other than multiple abrasions with contusions in the scalp, he did not undergo any imaging studies. He did not have any neurological deficits. The postoperative period was uneventful for the first patient and she was followed up for one month. The second patient was lost to follow-up. Conclusion: Successful management of two very rare cases of head injuries from Nepal are reported. Proper care and maintenance of the house-hold utensils that are constantly used may protect people from head injuries. Though natural calamities cannot always be avoided, simple measures like using an umbrella while going outdoors may protect individuals from head injuries due to hailstones.

\section{Keywords}

Craniocerebral trauma, Craniotomy, Skull base, Frontal sinus, Cerebrospinal fluid, Contusions

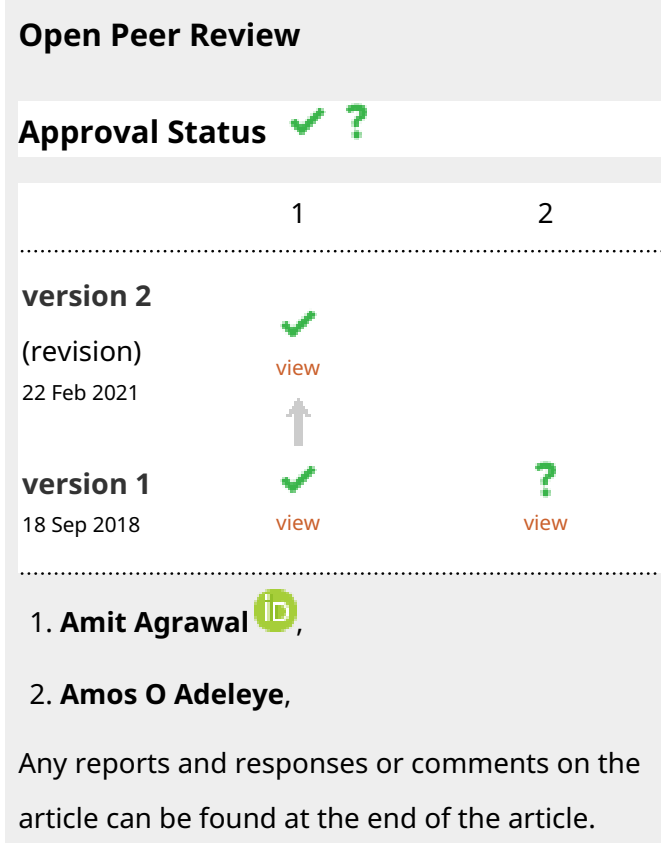


Corresponding author: Joe M. Das (drjoemdas@gmail.com)

Author roles: Das JM: Conceptualization, Formal Analysis, Investigation, Methodology, Resources, Software, Supervision, Validation, Visualization, Writing - Original Draft Preparation, Writing - Review \& Editing; Pokharel A: Conceptualization, Data Curation, Formal Analysis, Investigation, Methodology, Supervision, Validation, Writing - Review \& Editing; Sapkota R: Data Curation, Formal Analysis, Investigation, Resources, Visualization, Writing - Original Draft Preparation; Mishra M: Data Curation, Investigation, Methodology, Project Administration, Validation, Writing - Original Draft Preparation; Babu Aryal A: Data Curation, Investigation, Resources, Supervision, Writing - Original Draft Preparation

Competing interests: No competing interests were disclosed.

Grant information: The author(s) declared that no grants were involved in supporting this work.

Copyright: ( 2021 Das JM et al. This is an open access article distributed under the terms of the Creative Commons Attribution License, which permits unrestricted use, distribution, and reproduction in any medium, provided the original work is properly cited.

How to cite this article: Das JM, Pokharel A, Sapkota R et al. Case Report: Two cases of rare head injuries from Nepal [version 2; peer review: 1 approved, 1 approved with reservations] F1000Research 2021, 7:1483 https://doi.org/10.12688/f1000research.16225.2

First published: 18 Sep 2018, 7:1483 https://doi.org/10.12688/f1000research.16225.1 


\section{REVISED Amendments from Version 1}

The term "dal" has been defined. A new figure of the computed tomogram scan of the head (bone window) at the level of the anterior skull base has been included and the numbers denoting the figures have been rearranged. A more detailed description of the craniofacial fracture has been included in the text and in the figure legend of the 3D skull image.

Any further responses from the reviewers can be found at the end of the article mixed with blood in the periphery of the wound and there was mechanical ptosis of right eye. The patient was conscious and oriented. Emergency X-ray of skull (Figure 1) and computed tomography (CT) of the head (Figure 2) were done, which showed the foreign body just lateral to the root of nose on the right side with the right lateral wall of the nostril fractured and pushed inside. The force of the projectile led to a right naso-orbital fracture extending from the inferomedial orbital rim across the maxilla (just medial to the zygomaticofacial foramen) to the right nasal wall. The fracture also involved both anterior and

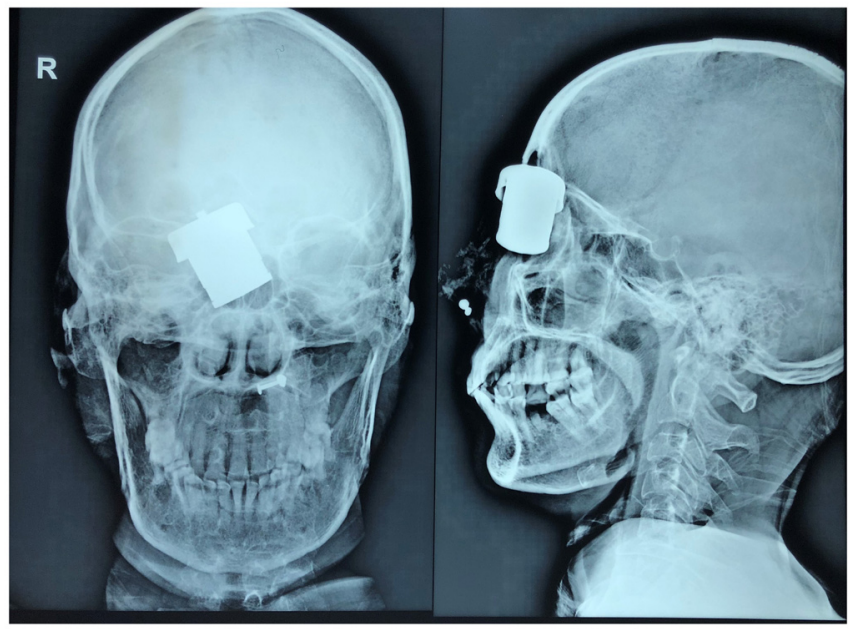

Hail is a variant of weather which can be occasionally harmfu as well as dangerous. It is a form of precipitation and consists of balls or irregular lumps of ice known as hailstones. Hailstones are composed mostly of ice and measure $5-50 \mathrm{~mm}$ in diameter. Hail is produced by cumulonimbus clouds otherwise known as thunderstorm clouds, which are transparent ice or made up of alternating layers of transparent and translucent ice, at least $1 \mathrm{~mm}$ thick ${ }^{9}$. Though hailstones are of small size usually, sometimes they are large enough to kill a person if it falls on the head. A previous newspaper report of a "hailstone massacre", which occurred centuries ago details this scenario ${ }^{10}$. The second case reported here is a case of mild head injury produced by falling hailstones. Surprisingly, head injury produced by hailstone has never been reported previously in the literature, to the best of our knowledge.

\section{Case 1}

A 55-year-old woman, with no known comorbidities, was cooking dal (a dish made of simmered and usually pureed and spiced legumes, as defined by the Merriam-Webster dictionary) using a pressure cooker at night. The patient doubted why there was no whistling after the expected time, and so tried to gently lift the pressure regulator, which suddenly gave way and was thrust into her face, like a projectile, near the right eye. There was no history of loss of consciousness, nasal bleed or seizures, though she had one episode of vomiting. She was a chronic smoker and occasional drinker of alcohol.

When she reached our emergency room in June 2018, her vital signs were stable. She had a wound of size $4 \times 2 \mathrm{~cm}$ in between the right eye and root of nose, which was deep and still had the cooker whistle lodged. There was cerebrospinal fluid (CSF)
Figure 1. Plain X-ray of skull, antero-posterior and lateral views showing the radio-opaque foreign body stuck in the anterior cranial fossa floor.

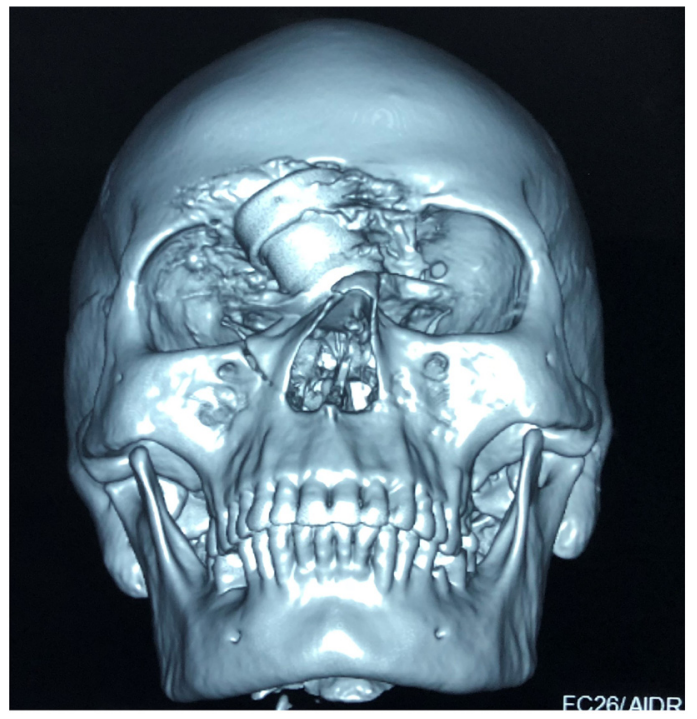

Figure 2. Plain Computed Tomogram of the face and skull (3D reconstruction) showing the foreign body and its relation to the right orbit and a right naso-orbital fracture extending from the inferomedial orbital rim across the maxilla (just medial to the zygomaticofacial foramen) to the right nasal wall. 
posterior walls of the right frontal sinus and was associated with pneumocephalus and a $1 \times 1 \mathrm{~cm}$ sized left frontal contusion (Figure 3 and Figure 4).

The patient underwent emergency bifrontal craniotomy. The right frontal sinus fracture with dural tear of size $0.5 \times 1 \mathrm{~cm}$ was noted and the foreign body (Figure 5) was retrieved through the fracture from the cranial aspect (Figure 6). The frontal sinus was exteriorized and packed with muscle and bone wax applied across the defect. Anterior cranial fossa was carpeted with pedicled pericranial flap and the wound was closed after replacing the bone flap. The wound at the site of foreign body was seen by our otorhinolaryngologist and was closed in layers. The nasal mucosa was intact and there was no injury to nasolacrimal duct. The fractured nasal bone was not disturbed as it could cause stenosis of the right nostril.

The patient was started on Meropenem $2 \mathrm{~g}$ thrice a day, Vancomycin $1 \mathrm{~g}$ twice a day and Metronidazole $500 \mathrm{mg}$ thrice a day as antibiotics, and levetiracetam $500 \mathrm{mg}$ twice a day as anticonvulstant, which were continued for one week. The patient's vision was fully preserved. The post-operative period was uneventful. Post-operative CT scan of brain showed resolving frontal contusion and she was discharged on post-operative day 8 . When she came for follow-up after one month, she was asymptomatic, the wound had healed fully and there was no CSF leak.

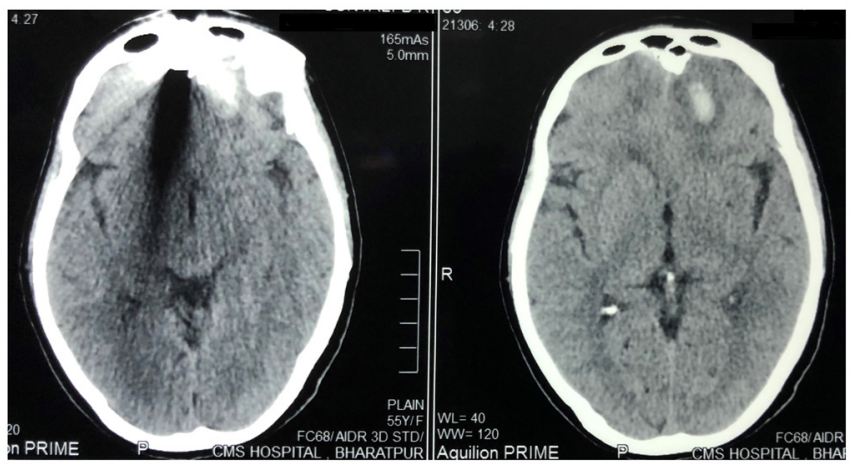

Figure 3. Plain Computed Tomogram of the brain (axial cuts) showing the left frontal contusion and metal artefact due to foreign body.

\section{Case 2}

An 85-year-old man presented to our neurosurgery out-patient department in May 2018 with complaint of headache following falling of hailstones on his head three days previously. He was a chronic smoker and alcoholic and did not have any comorbidities. He had no history of previous hospital admissions.

Following the incident, the patient did not lose consciousness, vomit, or have a seizure. He also did not have any nasal or ear bleed. On clinical examination, he was neurologically intact and there was no papilledema on examination of the fundus. The patient had three healing abrasions with contusions, each the size of around $1 \times 1 \mathrm{~cm}$ with local tenderness. Two abrasions were located in the left frontal region, behind hairline and one in the right parietal region, behind hairline (Figure 7). There was no clinical evidence of infection or skull fracture. Radiological imaging was not warranted and he was managed with $37.5 \mathrm{mg}$ of tramadol hydrochloride and $325 \mathrm{mg}$ of acetaminophen twice a day for five days. Though he was instructed to come for follow-up after one week, he did not turn up.

\section{Discussion}

The pressure cooker (PC), invented by the French-born British physicist Denis Papin in 1679, is a hermetically sealed pot that produces steam heat to cook food quickly. The PC heats water to produce very hot steam and as a result, the temperature inside it will increase to around $130^{\circ} \mathrm{C}$, which is much higher than the maximum heat produced by ordinary cookware. The main advantage of this much high temperature is that it penetrates food quickly so that cooking time is reduced without diminishing vitamin and mineral content ${ }^{11}$. The problem faced high altitude areas, like Nepal, is that boiling happens at low temperature due to reduced atmospheric pressure. PCs will increase the pressure so that cooking occurs at the appropriate temperature.

PC pressure regulator projectile injury to the face was first reported by Chattopadhyay et al. in $2010^{4}$. Altogether, there are five reports of this type of case (Table 1), four of them with significant ocular trauma. The case reported by Gupta et al. was similar to our case and had significant head injury ${ }^{5}$. In that case, the foreign body lodged transorbitally and was operated on promptly, even though the patient's vision was lost by the injury and led to the development of a brain abscess subsequently. Our patient was lucky enough for her eye to escape from the direct
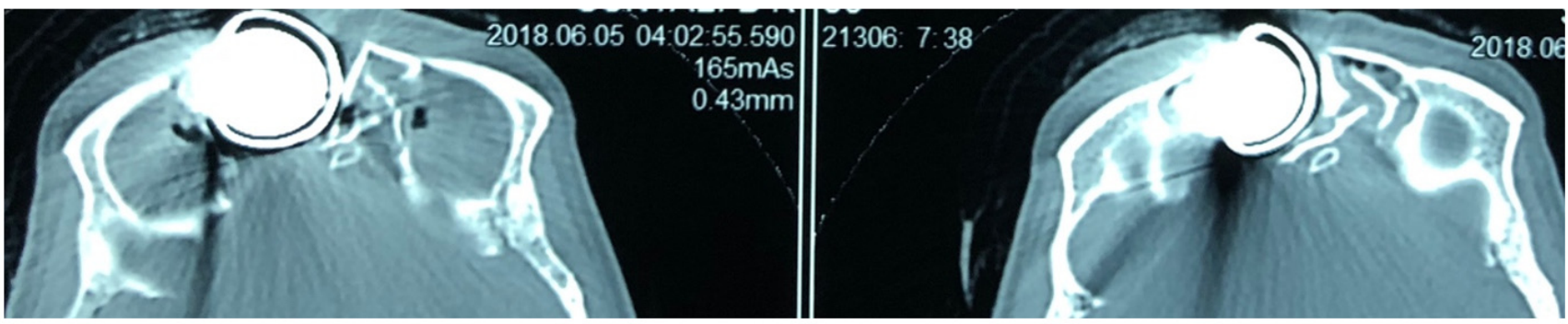

Figure 4. Plain Computed Tomogram of the head (bone window - axial cuts) at the level of frontal base showing the location of the projectile and the fractured right frontal sinus. 


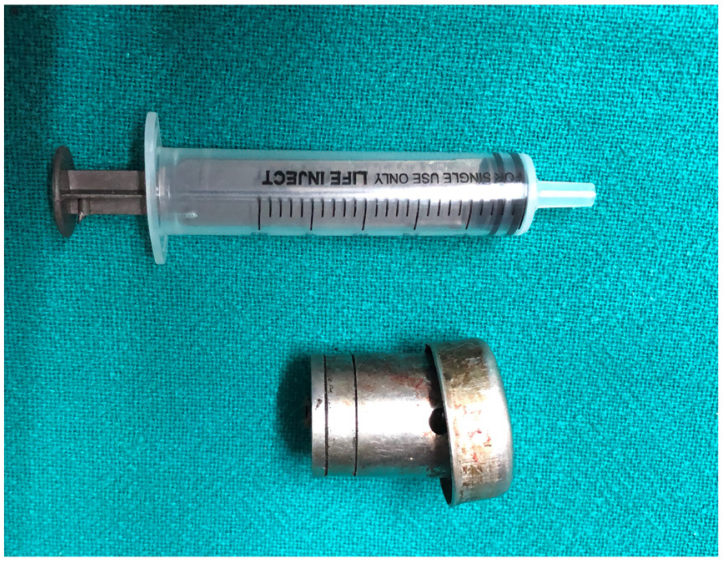

Figure 5. The retrieved foreign body measuring $3.0 \times 2.5 \mathrm{~cm}$ in size.

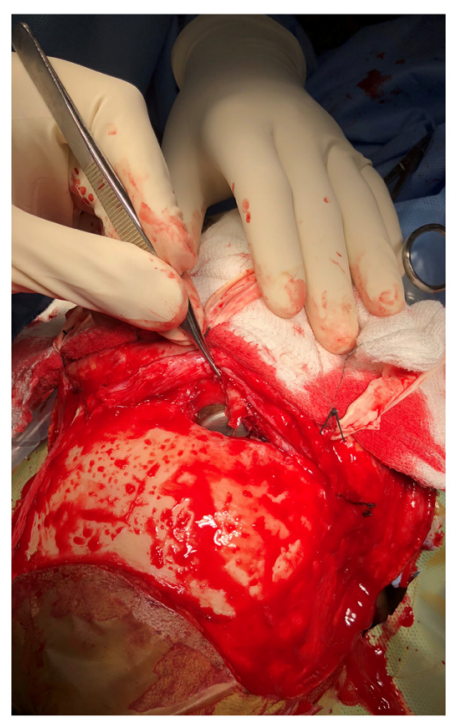

Figure 6. Intra-operative picture showing the fractured right frontal sinus with the foreign body in situ.

impact of foreign body and from further complications of surgery.

PCs can maintain high temperature $\left(121^{\circ} \mathrm{C}\right)$ and proper pressure $\left(1 \mathrm{~kg} / \mathrm{cm}^{2}\right)$ inside for cooking. The pressure is controlled inside by the vent weight (pressure regulator) and its spring action - excess steam goes out through the vent tube. Sometimes it can get blocked due to imperfect cleaning, excessive volume of water or overfilling with green leaves ${ }^{12}$. Then excess steam will accumulate inside, which can push the PC's lid or pressure regulator out with huge force. Such accidents can be reduced by proper maintenance of the cooker, cleaning the lid and vent valve and filling the objects inside the cooker up to the appropriate level.

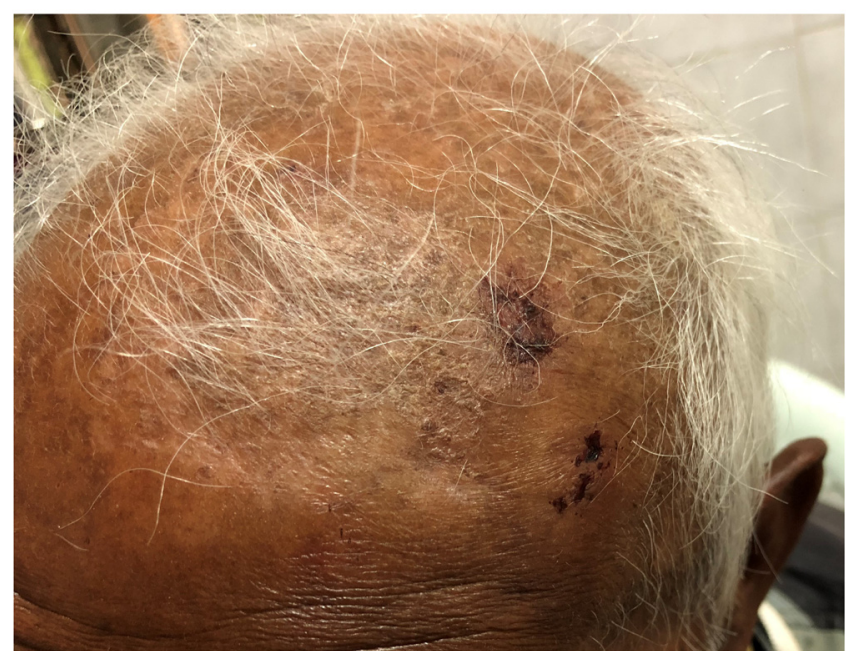

Figure 7. Scalp contusions and abrasions in the left frontal region produced by the impact of falling hailstones.

The projectile of a pressure regulator will almost always be directed towards the face (especially orbit) and skull. As has been reported previously, it is always safe to perform a craniotomy followed by removal of the foreign body for all foreign bodies, which have breached the dura, to prevent inadvertent damage to vital structures ${ }^{13}$. The patient had pneumocephalus with frontal sinus fracture, which was suggestive of a breach in the dura. If the foreign body is directly taken out blindly without exposing it through craniotomy, there is a chance that injury can occur to the brain as well as to the bridging vein at anterior skull base, if any ${ }^{14}$. This was the rationale for approaching the foreign body via cranium.

Hail is a form of frozen precipitation (hydrometeor) which originates in a thunderstorm cloud, scientifically known as cumulonimbus (thundercloud), which is composed of water droplets and ice crystals. There are upward forces in such clouds known as updrafts, and they carry raindrops upward into very cold areas of the atmosphere. In such areas, water droplets become super-cooled and freeze when coming into contact with condensation nuclei (small aerosols), thus forming small hailstones. The updraft then dissipates and these hailstones fall down. But these will be brought back into another updraft, and will be lifted up again. A layer of ice will get added to the hailstone and it grows in size with each ascent. Once a hailstone becomes too heavy to be supported by the updraft, it falls down from the cloud ${ }^{15}$. The main factors present in thunderstoms that are favorable to hail formation are strong updrafts, large liquid water contents, large cloud-drop sizes, and great vertical height $^{16}$. Hail usually falls during severe thunderstorms in the warm season, when the temperature on the surface of the earth rises above $20^{\circ} \mathrm{C}^{9}$.

Hailstone is an individual unit of hail. By convention, any frozen precipitation having a diameter of $5 \mathrm{~mm}$ or more is classified 
Table 1. Reports of craniofacial injuries caused by pressure regulator projectile of pressure cookers to date.

\begin{tabular}{|c|c|c|c|c|c|c|c|c|}
\hline Author (year) & $\begin{array}{l}\text { Age of } \\
\text { patient }\end{array}$ & Sex & $\begin{array}{l}\text { Site of } \\
\text { impact }\end{array}$ & $\begin{array}{l}\text { Neurological } \\
\text { examination }\end{array}$ & X-ray/CT finding & $\begin{array}{l}\text { Structures } \\
\text { involved }\end{array}$ & $\begin{array}{l}\text { Procedure } \\
\text { done }\end{array}$ & Outcome \\
\hline $\begin{array}{l}\text { Chattopadhyay } \\
\text { SS et al. }(2010)^{4}\end{array}$ & $32 y$ & $\mathrm{~F}$ & $\begin{array}{l}\text { Right } \\
\text { upper } \\
\text { eye lid }\end{array}$ & $\begin{array}{l}\text { Vision - PL } \\
\text { GCS-13 }\end{array}$ & $\begin{array}{l}\text { Disorganized globe } \\
\text { with impacted nozzle }\end{array}$ & $\begin{array}{l}\text { Right globe with } \\
\text { autoevisceration } \\
\text { of ocular } \\
\text { contents }\end{array}$ & $\begin{array}{l}\text { Glass ball } \\
\text { ocular implant } \\
\text { was placed } \\
\text { and scleral } \\
\text { laceration } \\
\text { repaired }\end{array}$ & Not mentioned \\
\hline $\begin{array}{l}\text { Gupta OP } \\
\text { et al. }(2013)^{5}\end{array}$ & $47 y$ & $\mathrm{~F}$ & $\begin{array}{l}\text { Left } \\
\text { forehead } \\
\text { and eye }\end{array}$ & $\begin{array}{l}\text { Vision - No PL } \\
\text { GCS - } 13\end{array}$ & $\begin{array}{l}\text { Metallic foreign } \\
\text { body inside left orbit } \\
\text { with basifrontal } \\
\text { contusion with } \\
\text { pneumocephalus }\end{array}$ & $\begin{array}{l}\text { Left orbital wall, } \\
\text { frontal sinus and } \\
\text { globe }\end{array}$ & $\begin{array}{l}\text { Evisceration } \\
\text { of left eye } \\
\text { with removal } \\
\text { of foreign } \\
\text { body }\end{array}$ & $\begin{array}{l}\text { Developed } \\
\text { brain abscess } \\
\text { after } 1 \text { month, } \\
\text { which was } \\
\text { evacuated. Final } \\
\text { neurological } \\
\text { outcome - good }\end{array}$ \\
\hline $\begin{array}{l}\text { Dobariya } \\
\text { et al. }(2014)^{6}\end{array}$ & $29 y$ & M & $\begin{array}{l}\text { Left } \\
\text { upper } \\
\text { eye lid }\end{array}$ & $\begin{array}{l}\text { Vision - No PL } \\
\text { GCS - } 14\end{array}$ & $\begin{array}{l}\text { Intruded whistle in left } \\
\text { orbit. No fracture }\end{array}$ & $\begin{array}{l}\text { Left globe with } \\
\text { autoevisceration } \\
\text { of ocular } \\
\text { contents }\end{array}$ & $\begin{array}{l}\text { Scleral } \\
\text { laceration } \\
\text { repaired }\end{array}$ & Not mentioned \\
\hline $\begin{array}{l}\text { Atreya } \\
\text { et al. }(2016)^{7}\end{array}$ & $62 y$ & $\mathrm{~F}$ & $\begin{array}{l}\text { Right } \\
\text { parotid } \\
\text { region }\end{array}$ & $\begin{array}{l}\text { Right LMN } \\
\text { facial palsy }\end{array}$ & $\begin{array}{l}\text { Rectangular shadow } \\
\text { over mandibular region }\end{array}$ & $\begin{array}{l}\text { Subcutaneous } \\
\text { tissue and facial } \\
\text { nerve }\end{array}$ & $\begin{array}{l}\text { Removal } \\
\text { and primary } \\
\text { closure }\end{array}$ & Not mentioned \\
\hline $\begin{array}{l}\text { Singh AK } \\
\text { et al. }(2016)^{8}\end{array}$ & $26 y$ & $\mathrm{~F}$ & $\begin{array}{l}\text { Between } \\
\text { root of } \\
\text { nose and } \\
\text { right eye } \\
\text { ball }\end{array}$ & $\begin{array}{l}\text { Vision - No PL } \\
\text { GCS - } 15\end{array}$ & $\begin{array}{l}\text { Fracture of medial } \\
\text { orbital wall with } \\
\text { penetration of the } \\
\text { foreign body for } 3 \\
\text { centimetres inside the } \\
\text { bony orbit }\end{array}$ & $\begin{array}{l}\text { Right globe with } \\
\text { autoevisceration } \\
\text { and exposed } \\
\text { uveal tissue with } \\
\text { oedematous } \\
\text { upper lid }\end{array}$ & $\begin{array}{l}\text { Evisceration, } \\
\text { suturing of } \\
\text { sclera and } \\
\text { conjunctiva. } \\
\text { Skin } \\
\text { lacerations } \\
\text { left to heal } \\
\text { by secondary } \\
\text { intention }\end{array}$ & $\begin{array}{l}3 \text { months } \\
\text { - referred } \\
\text { to ocularist } \\
\text { for custom- } \\
\text { made ocular } \\
\text { prosthesis }\end{array}$ \\
\hline Our case & 55 y & $\mathrm{F}$ & $\begin{array}{l}\text { Between } \\
\text { root of } \\
\text { nose and } \\
\text { right eye } \\
\text { ball }\end{array}$ & $\begin{array}{l}\text { Vision } \\
\text { - Normal } \\
\text { GCS - } 15\end{array}$ & $\begin{array}{l}\text { Foreign body just } \\
\text { lateral to the root of } \\
\text { nose on the right side } \\
\text { with the right lateral } \\
\text { wall of nostril fractured } \\
\text { and pushed inside. } \\
\text { There was fracture } \\
\text { involving the right } \\
\text { frontal sinus with } \\
\text { pneumocephalus and } \\
1 \times 1 \mathrm{~cm} \text { sized left frontal } \\
\text { contusion }\end{array}$ & $\begin{array}{l}\text { Right orbital } \\
\text { wall, nasal bone, } \\
\text { frontal sinus, } \\
\text { frontal lobes }\end{array}$ & $\begin{array}{l}\text { Bifrontal } \\
\text { craniotomy } \\
\text { and removal } \\
\text { of foreign } \\
\text { body followed } \\
\text { by primary } \\
\text { closure }\end{array}$ & $\begin{array}{l}1 \text { month } \\
\text { - Neurologically } \\
\text { intact }\end{array}$ \\
\hline
\end{tabular}

CT - Computed tomogram, y - years, M - Male, F - Female, PL - Perception of light, GCS - Glasgow Coma Scale Score, LMN - Lower motor neuron

as hailstone, whereas smaller particles of similar origin are known as either ice pellets or snow pellets ${ }^{17}$. In the Cambridge dictionary, hailstone is defined as "a small, hard ball of ice that falls from the sky like rain"18. Most of the hail storms are made up of hailstones of different sizes. Usually only the large ones pose serious risk to people caught in the open. According to the Guinness book of world records, the heaviest hailstones ever recorded weighed approximately 1 kilogram and are reported to have killed 92 people in the Gopalganj area of Bangladesh on 14 April $1986^{19}$. The largest hailstone recently recovered in the USA fell in Vivian, South Dakota on June 23, 2010 with a diameter of 8 inches and a circumference of 18.62 inches. It also weighed almost 1 kilogram $^{20}$. One of the most lethal hailstorms in history, leading to the death of hundreds of nomads, occurred around AD 850 close to the glacial Roopkund Lake in the remote Himalayan Gahrwal region ${ }^{10}$.

Even though there is a high frequency of occurrence of thunderstoms in the tropics, hail is actually less common in these regions, compared to the mid-latitudes, as the atmosphere over the tropics is warmer over a much greater height. Hail is common in mountain ranges because mountains force horizontal winds to move suddenly upwards (orographic lifting). This intensifies the updrafts within thunderstorms which makes hail more likely ${ }^{21}$. Hence hail is relatively common in Nepal.

There has been no report of hail falling on the head and producing injury, though hail is known to cause widespread damage to 
farms, houses, animals and humans. The present case did not have any criteria for radiological imaging as per the Canadian $\mathrm{CT}$ rule ${ }^{22}$. Moreover, the patient presented three days after the incident. In Nepal, patients may not be presenting immediately after the injury, either because they have only mild symptoms or they have to travel a long distance to reach a tertiary care hospital. The main limitation of this case is that there is no proper follow-up.

\section{Conclusion}

Head injury can occur wherever you are - it does not matter whether you are indoors or outdoors. Here this fact is stressed with the help of two different and extremely rare types of head injuries. Some simple manoeuvres, such as proper maintenance of equipment and utensils you are working with or taking an umbrella while going for a morning walk, may protect individuals from such calamities.

\section{Consent}

Written informed consent for publication of their clinical details and/or clinical images was obtained from both patients.

\section{Data availability}

All data underlying the results are available as part of the article and no additional source data are required.
1. Perera VA, Karunadasa K, Perera C: $A$ case series of domestic pressure cooker burns. Ceylon Med J. 2012; 57(1): 49. PubMed Abstract | Publisher Full Text

2. Gundeslioglu AO, Yenidunya $\mathrm{MO}$ : Burn and mandible fracture due to pressure cooker explosion. J Craniofac Surg. 2010; 21(5): 1631-3. PubMed Abstract | Publisher Full Text

3. Calderon-Miranda WG, Escobar-Hernandez N, Moscote-Salazar LR, et al: Traumatic brain injury due to pressure cooker explosion in a child: case report. Romanian Neurosurgery. 2016; 30(2): 300-302. Reference Source

4. Chattopadhyay SS, Mukhopadhyay U, Saurabh K: An unusual case of penetrating ocular trauma with a pressure cooker. Oman J Ophthalmol. 2010; 3(2): 89-90.

PubMed Abstract | Publisher Full Text | Free Full Text

5. Gupta OP, Roy K, Ghosh S, et al.: An unusual penetrating transorbital craniocerebral injury. The Indian Journal of Neurotrauma. 2014; 11(1): 53-6. Publisher Full Text

6. Dobariya V, Sheikh KM, Shastri M, et al.: An unusual case of penetrating ocular trauma with a pressure cooker whistle. Delhi J Ophthalmol. 2014; 24: 207-208.

Publisher Full Text

7. Atreya A, Kanchan T, Nepal S: Pressure Cooker-A Potential Hazard in Domestic Setting. Kathmandu Univ MedJ (KUMJ). 2016; 14(54): 181-3. PubMed Abstract

8. Singh AK: An Unusual Intraorbital Foreign Body. Delhi J Ophthalmol. 2016; 27(3): 213-4. Reference Source

9. Akhmedovic IS: About the Mechanism of the Hail Formation. Science Discovery. 2014; 2(2): 27-33. Publisher Full Text

10. Orr D: Giant Hail Killed More than $\mathbf{2 0 0}$ in Himalayas. The Telegraph. 2004; accessed June 22, 2018

Reference Source
11. The Editors of Encyclopaedia Britannica: Pressure cooker. Encyclopcedia Britannica. accessed June 22, 2018. Reference Source

12. Sandhir RK, Sandhir M: Accidental pressure cooker lid blow-out. Burns. 1992; 18(5): 438.

PubMed Abstract | Publisher Full Text

13. Das JM, Chandra S, Prabhakar RB: Penetrating brain injury with a bike key: a case report. Ulus Travma Acil Cerrahi Derg. 2015; 21(6): 524-6. PubMed Abstract | Publisher Full Text

14. Zhang D, Chen J, Han K, et al.: Management of Penetrating Skull Base Injury: A Single Institutional Experience and Review of the Literature. Biomed Res Int. 2017; 2017: 2838167.

PubMed Abstract | Publisher Full Text | Free Full Text

15. The National Severe Storms Laboratory. accessed June 22, 2018. Reference Source

16. Considine DM, Considine GD: Precipitation and hydrometeors. In: Considine DM, Considine GD, eds. Van Nostrand's Scientific Encyclopedia. $8^{\text {th }}$ ed. New York: Springer Science+Business Media; 1995; 2538 Publisher Full Text

17. Glossary of meteorology. accessed on June 22, 2018. Reference Source

18. Cambridge dictionary. accessed on June 22, 2018 Reference Source

19. Guinness Book of World Records. accessed on June 22, 2018 Reference Source

20. Arndt D: Official Documentation of the Verification of the Vivian, SD record setting hailstone of 2010. 2010; accessed on June 22, 2018. Reference Source

21. Hail. National Environment Agency. accessed on 22 June, 2018.

22. Davey K, Saul T, Russel G, et al:: Application of the Canadian Computed Tomography Head Rule to Patients With Minimal Head Injury. Ann Emerg Med. 2018; 72(4): 342-350. PubMed Abstract | Publisher Full Text 


\section{Open Peer Review}

\section{Current Peer Review Status:}

\section{Version 2}

Reviewer Report 23 February 2021

https://doi.org/10.5256/f1000research.30538.r79981

(C) 2021 Agrawal A. This is an open access peer review report distributed under the terms of the Creative Commons Attribution License, which permits unrestricted use, distribution, and reproduction in any medium, provided the original work is properly cited.

\section{Amit Agrawal}

No new comments.

Competing Interests: No competing interests were disclosed.

I confirm that I have read this submission and believe that I have an appropriate level of expertise to confirm that it is of an acceptable scientific standard.

\section{Version 1}

Reviewer Report 12 August 2020

https://doi.org/10.5256/f1000research.17719.r67439

(C) 2020 Adeleye A. This is an open access peer review report distributed under the terms of the Creative Commons Attribution License, which permits unrestricted use, distribution, and reproduction in any medium, provided the original work is properly cited.

\section{Amos O Adeleye}

This is generally an interesting clinical vignette by these authors, especially the first case. We are of the opinion actually that the authors have enough literature base as well as the clinical materials of the first case to do this write-up simply as a case-based literature review of head injury/traumatic brain injury from projectiles from house-hold pressure cookers.

The second case does not warrant any scientific report in our opinion, not by the near normal 
clinical acute-event / immediate post-event period status of the patient, as well as the very minimal body harm to the patient.

Having said that, we like to make some of the observations below concerning the authors' otherwise well-written paper.

The figure 2, the plain 3-D reconstruction of the cranial CT bone windows, contains more information that just 'the foreign body and its relation to the orbit'. There is the impression of a right naso-orbital fracture extending from the inferomedial orbital rim across the maxilla (just medial to the zygomasticofaical foramen) to the right nasal wall. One would expect all this to reflect in the authors' case description (and the figure legend) by way of emphasis on the apparent destructive impact of the house-hold utensil turned projectile.

Case 1

"A 55-year-old woman, with no known comorbidities, was cooking dal using a pressure...." What's 'dal' please, for us international readers?

"There was fracture involving the right frontal sinus with pneumocephalus and $1 \times 1 \mathrm{~cm}$ sized left frontal contusion (Figure 3)."

The figure 3 referred to here is a brain, not a bone, window of the cranial CT. The frontal sinus fracture being described could therefore hardly be appreciated. We had actually wondered why the authors did not render some of the images at this frontobasal level in the bone windows. That's what would have been more instructive for this part of the work

Is the background of the case's history and progression described in sufficient detail? Yes

Are enough details provided of any physical examination and diagnostic tests, treatment given and outcomes?

Partly

Is sufficient discussion included of the importance of the findings and their relevance to future understanding of disease processes, diagnosis or treatment?

Yes

Is the case presented with sufficient detail to be useful for other practitioners? Yes

Competing Interests: No competing interests were disclosed.

Reviewer Expertise: Clinical neurological surgery,

I confirm that I have read this submission and believe that I have an appropriate level of expertise to confirm that it is of an acceptable scientific standard, however I have significant reservations, as outlined above. 
Author Response 30 Oct 2020

Joe M Das

Thank you for looking into our article in detail and providing constructive feedback.

The article has been amended as suggested.

1. The term "dal" has been explained.

2. A detailed description of the facial fracture is included.

3. A new figure showing the fractured frontal sinus has been provided.

Competing Interests: No competing interests to disclose.

Author Response 11 Nov 2020

\section{Joe M Das}

This is generally an interesting clinical vignette by these authors, especially the first case. We are of the opinion actually that the authors have enough literature base as well as the clinical materials of the first case to do this write-up simply as a case-based literature review of head injury/traumatic brain injury from projectiles from house-hold pressure cookers. -

\section{Thank you.}

The second case does not warrant any scientific report in our opinion, not by the near normal clinical acute-event / immediate post-event period status of the patient, as well as the very minimal body harm to the patient. - We still would like it to be published as there are not many reports on the harms this natural calamity can do to humans.

Having said that, we like to make some of the observations below concerning the authors' otherwise well-written paper.

The figure 2, the plain 3-D reconstruction of the cranial CT bone windows, contains more information that just 'the foreign body and its relation to the orbit'. There is the impression of a right naso-orbital fracture extending from the inferomedial orbital rim across the maxilla (just medial to the zygomasticofaical foramen) to the right nasal wall. One would expect all this to reflect in the authors' case description (and the figure legend) by way of emphasis on the apparent destructive impact of the house-hold utensil turned projectile. We have added the details of the fracture in the case description and figure legend, as suggested.

\section{Case 1}

"A 55-year-old woman, with no known comorbidities, was cooking dal using a pressure...." What's 'dal' please, for us international readers? We have added a simple definition of dal.

"There was fracture involving the right frontal sinus with pneumocephalus and $1 \times 1 \mathrm{~cm}$ sized left frontal contusion (Figure 3)." 
The figure 3 referred to here is a brain, not a bone, window of the cranial CT. The frontal sinus fracture being described could therefore hardly be appreciated. We had actually wondered why the authors did not render some of the images at this frontobasal level in the bone windows. That's what would have been more instructive for this part of the work. We have added a new image of the bone window at the frontobasal level.

Competing Interests: None.

Reviewer Report 03 December 2018

https://doi.org/10.5256/f1000research.17719.r40762

(C) 2018 Agrawal A. This is an open access peer review report distributed under the terms of the Creative Commons Attribution License, which permits unrestricted use, distribution, and reproduction in any medium, provided the original work is properly cited.

\section{Amit Agrawal}

In this article the authors report two interesting cases of head injuries. One is due to accidental explosion of a man-made device and another one is due to a natural calamity.

In the second case, it is interesting to note that hailstorm is a natural phenomenon, and there are number of incidences reported in news ranging from minor injuries to fatal incidences both to humans as well as to livestock.

As the authors have suggested, the systematic information for such injuries is lacking. This single case can be taken as message that we need to further expand the scope of the incidence and impact of injuries due to natural calamities on human life.

Is the background of the case's history and progression described in sufficient detail? Partly

Are enough details provided of any physical examination and diagnostic tests, treatment given and outcomes?

Partly

Is sufficient discussion included of the importance of the findings and their relevance to future understanding of disease processes, diagnosis or treatment?

Partly

Is the case presented with sufficient detail to be useful for other practitioners? Partly 
Competing Interests: No competing interests were disclosed.

I confirm that I have read this submission and believe that I have an appropriate level of expertise to confirm that it is of an acceptable scientific standard.

\section{Author Response 11 Nov 2020}

\section{Joe M Das}

In this article the authors report two interesting cases of head injuries. One is due to accidental explosion of a man-made device and another one is due to a natural calamity.

In the second case, it is interesting to note that hailstorm is a natural phenomenon, and there are number of incidences reported in news ranging from minor injuries to fatal incidences both to humans as well as to livestock.

As the authors have suggested, the systematic information for such injuries is lacking. This single case can be taken as message that we need to further expand the scope of the incidence and impact of injuries due to natural calamities on human life. Thank you for understanding the major reason for including the second report in our article.

Competing Interests: None.

The benefits of publishing with F1000Research:

- Your article is published within days, with no editorial bias

- You can publish traditional articles, null/negative results, case reports, data notes and more

- The peer review process is transparent and collaborative

- Your article is indexed in PubMed after passing peer review

- Dedicated customer support at every stage

For pre-submission enquiries, contact research@f1000.com 